\title{
Second Best? Trends and Linkages in the Informal Economy in South Africa ${ }^{1}$
}

\author{
Richard Devey \\ Caroline Skinner \\ Imraan Valodia \\ School of Development Studies \\ University of KwaZulu-Natal \\ valodia@ukzn.ac.za
}

Development Policy Research Unit

February 2006

Working Paper 06/102

ISBN 1-920055-21-5

1 This paper was written for the Human Sciences Research Council 2005-6 edition of the State of the Nation edited by Bulungu, Daniel, Southall and Lutchman. The paper is being published as a DPRU working paper to disseminate the findings among labour market analysts. Feedback is welcomed. 


\section{Abstract}

The idea of a 'second economy' has become a feature of recent government economic policy. In this paper we focus on one important element of the second economy - the informal economy. We analyse the nature of the informal economy in South Africa, providing some descriptive statistics and analysis to highlight the nature and extent of the informal economy. Given the present prominence of the 'second economy' concept, we provide some analysis of the efficacy of current government support measures to the informal economy, concluding that these are few and far between, patchy and incoherent, and largely ineffective. We then examine linkages between employment in the formal and the informal economy arguing that, contrary to the views of the President and the ANC, there are in fact fairly close linkages between the formal economy and the informal economy. Finally, by way of conclusion, we use the evidence provided in the paper to comment on the accuracy and relevance of the 'second economy' concept.

\section{Acknowledgements}

This paper draws on research conducted for a larger research programme on the informal economy in South Africa, funded by the International Development Research Centre (IDRC) and the South Africa-Netherlands Research Programme on Alternatives in Development (SANPAD). The HSRC commissioned us to write a number of papers on the informal economy. Many of the ideas in this paper draw on work for the HSRC. We are grateful also to Women in Informal Employment: Globalising and Organising (WIEGO), an international network of researchers and practitioners interested in work in the informal economy, who have supported our research programme.

Development Policy Research Unit

Tel: +2721650 5705

Fax: +27 216505711
Information about our Working Papers and other published titles are available on our website at: http://www.commerce.uct.ac.za/dpru/ 


\section{Table of Contents}

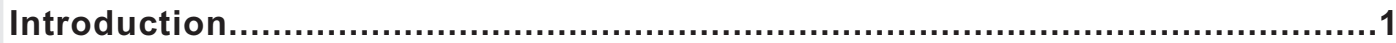

The Informal Economy: Conceptual Issues and Definitions............................................4

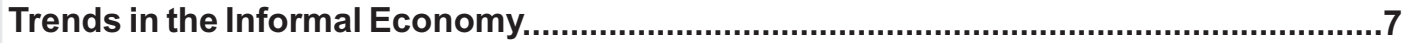

Government Policy on the Informal Economy...........................................................

Linkages between the Formal and Informal Economy...............................................16

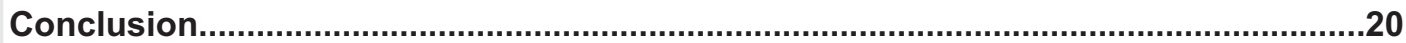

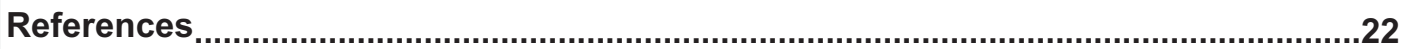




\section{Introduction}

In August 2003, President Mbeki introduced the idea of South Africa being characterised by a 'first economy' and a 'second economy' operating side by side. In November, in an address to the National Council of Provinces he stated:

"The second economy (or the marginalised economy) is characterised by underdevelopment, contributes little to GDP, contains a big percentage of our population, incorporates the poorest of our rural and urban poor, is structurally disconnected from both the first and the global economy and is incapable of self generated growth and development."

This idea of a 'second economy' is increasingly part of policy rhetoric at all levels of state. For example, the KwaZulu-Natal Minister for Finance and Economic Development, Dr Zweli Mkhize began his 2005 budget speech with a description of the economy using the analogy of an apartheid era train with the first economy occupying the first class compartments and the second economy being the second and third class sections. Having made substantial reference to the notion throughout the speech he argues that interventions in the second economy are 'even more crucial' than projects aimed at stimulating growth in the first economy.

In his 2004 State of the Nation Speech, President Mbeki argues that the:

"...core of our response to all these challenges is the struggle against poverty and underdevelopment, which rests on three pillars. These are: encouraging the growth and development of the first economy, increasing its possibility to create jobs; implementing our programme to address the challenges of the second economy; and, building a social security net to meet the objective of poverty alleviation."

The governing party elaborated on the notion of a dual economy by characterising the second economy as:

"The first and second Economies in our country are separated from each other by a structural fault. ... Accordingly, what we now have is the reality ... of a "mainly informal, marginalised, unskilled economy, populated by the unemployed and those unemployable in the formal sector". The second economy is caught in a "poverty trap". It is therefore unable to generate the internal savings that would enable it to achieve the high rates of investment it needs. Accordingly, on its own, it is unable to attain rates of growth that would ultimately end its condition of underdevelopment." (ANC Today, Volume 4, No. 47, 26 November-2 December 2004) 
In his 2005 State of the Nation Speech, Mbeki again refers to the concept of the 'second economy' arguing that:

"We must achieve new and decisive advances towards ... eradicating poverty and underdevelopment, within the context of a thriving and growing first economy and the successful transformation of the second economy..."

In outlining what government will do about transforming the second economy, the President has this to say:

"To take the interventions in the second economy forward ... additional programmes will be introduced or further strengthened by April 2005, as part of the Expanded Public Works Programme."

Although the President does not himself refer to the informal economy, the quote from $\underline{\text { ANC }}$ Today above shows that, within the ruling party at least, the informal economy is seen as being located in the second economy. Further, the ANC sees the second economy, and presumably the informal economy, as being structurally disconnected from the mainstream of the economy.

Arguments about dualism and the relationship between the mainstream of the economy and the periphery have characterised much of South African historiography. This is most prominently captured in the debates of the early 1970s about the relationship between apartheid and capitalism in South Africa with liberals arguing that capitalism would ultimately undermine apartheid as more and more of the African periphery came to be incorporated into the mainstream of the economy (see Lipton, 1985 and O'Dowd, 1978) and Marxists arguing that there was in fact a close, but exploitative, relationship between the mainstream and the periphery (see Legassick, 1974 and Wolpe, 1972). The re-emergence of a dualist view of the economy is significant not only because it is being articulated by the President and is at odds with the way in which the ANC has traditionally viewed South African society, but also because it seems to inform much of the policy focus of the ANC. Not having had a definitive statement from the President, we can only speculate on why he chooses to use the terms first and second economy, rather than formal and informal economy. As we shall see, these definitions matter. The President's view of the second economy includes the unemployed implying he is using a conceptualisation of the economy that moves beyond a simple formal-informal dichotomy.

The articulation of the first and second economy conceptualisation of South Africa by the Presidency coincided, we would argue, with a refocusing of economic policy in South Africa (see Padayachee and Valodia, 2001). This conceptualisation tacitly acknowledges the failure of the trickle down economic growth policies so central to the post-1996 GEAR era and informs much of government's more recent emphasis on poverty alleviation. However, the dualism suggested by arguments about a 'structural' break between the first and second 
economy allow government to argue that its economic policies have been successful for the first economy (see Naidoo, 2004) and, as a result of these successes, government is now able to address issues of poverty and unemployment in the second economy. As we demonstrate below, there is in fact a close relationship between the first and second economy (although, admittedly, we focus only on the informal economy) and government policy for the second economy is either absent, and where it does exist, it is piecemeal and ineffective.

In the absence of a coherent conceptualisation of and any systematic data on the second economy, we focus, in this paper, on one important element of the second economy - the informal economy. We analyse the nature of the informal economy in South Africa, providing some descriptive statistics and analysis to highlight the nature and extent of the informal economy. Given the present prominence of the 'second economy' concept, we provide some analysis of the efficacy of current government support measures to the informal economy, concluding that these are few and far between, patchy and incoherent, and largely ineffective. We then examine linkages between employment in the formal and the informal economy arguing that, contrary to the views of the President and the ANC, there are in fact fairly close linkages between the formal economy and the informal economy. Finally, by way of conclusion, we use the evidence provided in the paper to comment on the accuracy and relevance of the 'second economy' concept. 


\section{The Informal Economy: Conceptual Issues and Definitions}

At this point it is useful to clarify what the informal economy, or the informal sector, comprises. Since Keith Hart first coined the phrase 'informal sector' in the early 1970's to describe the range of subsistence activities of the urban poor, there has been considerable debate about what exactly the term refers to. The most quoted definition is that contained in the International Labour Organisation's Kenya Report (1972:6) in which informal activities are defined as 'a way of doing things', characterised by 'ease of entry; reliance on indigenous resources; family ownership of enterprises; small scale of operation; labour intensive and adapted technology; skill acquired outside of the formal school system and unregulated and competitive markets'.

Over the years the definition has evolved, as has the character of the phenomenon it aims to describe. Increasingly informal activities are the result of formal firms 'informalising'. Further, there are supply relations from the formal to the informal. These trends deem some of the characteristics identified in the ILO definition nonsensical. Lund and Srinivas (2000:9) point out "we do not think of formal sector procurers of fruit and vegetables from agribusiness who supply to informal traders as 'trading in indigenous resources'". A machinist doing piecework in the clothing industry is as likely to have acquired her skills in the formal education system as outside of it.

Castells and Portes (1989:12) describe the informal economy as a 'common sense' notion that cannot be captured by a strict definition. Although the authorities writing on the definition of the informal sector differ markedly as to what criteria they use to define the 'informal sector' and as to the relative weighting of different criteria, a criterion common to all definitions is that these are economic activities which are small scale and elude certain government requirements or, as Castells and Portes (1989:12) state, are 'unregulated by the institutions of society, in a legal and social environment in which similar activities are regulated.' Examples of such requirements are registration, tax and social security obligations and health and safety rules.

For our purposes, two important points are worth noting. First the term 'informal sector' disguises a significant degree of heterogeneity. Informal activities encompass different types of economic activity (trading, collecting, providing a service and manufacturing), different employment relations (the self-employed, paid and unpaid workers and disguised wage workers) and activities with different economic potential (survivalist activities and successful small enterprises). A second and related problem is the distinction between the formal and informal 'sectors' as if there was a clear line dividing the two. Closer analysis of this phenomenon demonstrates that they are integrally linked. There are few examples of informal operators who are not linked (either through supply or customer networks) into the formal economy. As Peattie (1987:858) points out, 'if we think about the world in terms of a 
formal and informal sector we will be glossing over the linkages which are critical for a working policy and which constitute the most difficult elements politically in policy development.'

Using the term informal 'economy' rather than informal 'sector' partially addresses such concerns. The term economy implies a greater range of activities than sector. If both formal and informal activities are seen as part of the economy we are better able to see the linkages between the two. Implied in the notion 'in'formal is that there is a formal, a norm, against which these other activities can be compared. As with any norm this will be time and context specific. With respect to the labour market Eapen (2001:2390) points out how some analysts define informality in terms of the absence of characteristics that belong to 'formal' activities like security/regularity of work, better earnings, existence of non-wage and long-term benefits, protective legislation and union protection. She goes on to point out that in a situation in which a number of activities within the formal sector are getting 'informalised' and private, small scale processing / manufacturing enterprises are growing, 'the borderline becomes blurred'. Considering this issue from another angle, Bromley (1995:146) asks 'if an enterprise is required to have six official permits, for example, but only has five, should it be considered informal even when the sixth derives from a moribund regulation that most entrepreneurs ignore?' He goes on to conclude 'formality and informality are really the opposite poles of a continuum with many intermediate and mixed cases' (Bromley, 1995:146).

For statistical purposes, the accepted international standard for defining the 'informal sector' was agreed in a resolution at the $15^{\text {th }}$ International Conference for Labour Statistics (ICLS). An important criterion of the ICLS definition is that employment in the informal sector is based on the characteristics of the enterprise in which the person is employed instead of the characteristics of the worker employed. The ICLS definition recommends that informal sector be defined in terms of one or more of the following criteria:

a) Non-registration of the enterprise in terms of national legislation such as taxation or other commercial legislation.

b) non-registration of employees of the enterprise in terms of labour legislation.

c) small size of the enterprise in terms of the numbers of people employed.

Statistics South Africa (StatsSA) uses this enterprise-based definition in order to derive estimates of informal employment in South Africa. The ILO (2002) and the $17^{\text {th }}$ ICLS have recently proposed an alternative definition which is based on the employment characteristics of the worker. According to this definition - presented at the 2002 International Labour Conference - the informal economy comprises informal employment (without secure contracts, worker benefits or social protection) of two kinds. The first is informal employment in informal enterprises (small unregistered or unincorporated enterprises) including employers, employees, own account operators and unpaid family 
workers in informal enterprises. The second is informal employment outside informal enterprises (for formal enterprises, for households or with no fixed employer), including: domestic workers, casual or day labourers, temporary or part-time workers, industrial outworkers (including home based workers) and unregistered or undeclared workers. ${ }^{2}$

The difference between these definitions is captured in Figure 1. The enterprise-based definition, currently used by StatsSA, is made up of cells 3 and 4 with the enterprise being the unit of analysis. In contrast, the new employment-based definition, now recommended by both the ILO and the International Conference of Labour Statistics, examines the nature of the work being performed and defines the informal economy as being made up of cells two and four. An issue that arises is whether the employment-based definition would be more appropriate to capture the informal economy in South Africa. In related work, we have argued that the employment-based definition would be more appropriate (see Devey et al, 2006).

Figure 1: Formal and Informal Employment - Definitional Differences

\begin{tabular}{|l|c|c|}
\hline Production units & \multicolumn{2}{|c|}{ Types of jobs } \\
\hline & Formal employment & Informal employment \\
\hline Formal enterprises & 1 & 2 \\
\hline Informal enterprises & 3 & 4 \\
\hline
\end{tabular}

Key: $\quad$ Formal employment=1; Enterprise based definition of the informal sector $=3+4$; Informal employment i.e. employment based definition $=2+4$

2 Statisticians use the term 'informal sector' to refer to informal enterprises and 'informal economy' to refer to informal employment in both informal and formal enterprises. In academic and policy arena, given the connotation of the term 'sector', as outlined in this section, we prefer the term informal economy combined with the explanation of whether the enterprise or employment-based definition is being used. 


\section{Trends in the Informal Economy}

Internationally, there is a growth in the numbers of people working in the informal economy, either self-employed in unregistered enterprises or as wage workers in unprotected jobs. A recent collation of international statistics on the informal economy states: 'Informal employment comprises one half to three quarters of non-agricultural employment in developing countries' (ILO, 2002:7). Table 1 lists the percentages in regions.

\section{Table 1 : Informal Employment as a Proportion of Non Agricultural Employment}

\begin{tabular}{|l|r|}
\hline Region & Percentage \\
\hline North Africa & $48 \%$ \\
\hline Sub-Saharan Africa & $72 \%$ \\
\hline Latin America & $51 \%$ \\
\hline Asia & $65 \%$ \\
\hline
\end{tabular}

Source: Adapted from ILO, 2002:7

It is thus clear that in many parts of the world informal employment is the norm. Further Chen (2001:72) cites that 83 per cent and 93 per cent of new jobs were created in the informal economy in Latin America and Africa respectively. This indicates that the trend of informalisation is unlikely to be reversed. Informal employment, however, is not only a developing country phenomenon. The ILO (2002:7) states that three categories of non standard or atypical work - self-employment, part-time work and temporary work - comprise 30 per cent of overall employment in 15 European countries and 25 per cent of total employment in the United States.

Table 2 shows the broad trends in the labour market in South Africa over the period 1997 to 2003. There has been a sustained growth in unemployment (Table 2). Figure 2, using figures presented in Table 2, graphically represents the workforce i.e. those who are working. Employment in the formal economy has shown very limited growth over the period (Figure 2). One segment of the economy in which seems to have generated employment is the informal economy. ${ }^{3}$ In this segment of the labour force ${ }^{4}$, employment increased from 965 000 in October 1997 to 1.9 million in September 2003, more than doubling over a period of 6 years. For a number of reasons, this trend must, however, be treated with caution. First, we are using data from the October Household Survey for the period 1997-1999 and the Labour

3 The other area of employment showing rapid growth (and then rapid decline) is subsistence agriculture. See Aliber (2003) for an analysis of the trend in subsistence agriculture.

4 Statistics South Africa defines someone as working in what they call the 'informal sector' if they work in a firm that is unregistered i.e. the enterprise definition is being used. 
Force Survey for the period 2000-2003, two surveys which are not directly comparable. Devey et al (2006) point to other problems with these estimates of informal employment. They highlight the fact that there are several inconsistencies in the data on informal employment. More importantly, they show that Statistics South Africa has improved its capturing of informal employment so that at least part of the increasing trend in informal employment is simply better capturing of the phenomenon. Notwithstanding these difficulties it is now widely accepted that informal employment has grown since the political transition and that, as the data shows, this growth has declined in recent years (see Devey et al, 2006).

Table 2 : Labour Market Status of Workers in South Africa, 1997-2003

\begin{tabular}{|l|r|r|r|r|r|r|r|}
\hline & 1997 & $\mathbf{1 9 9 8}$ & $\mathbf{1 9 9 9}$ & $\mathbf{2 0 0 0}$ & $\mathbf{2 0 0 1}$ & $\mathbf{2 0 0 2}$ & $\mathbf{2 0 0 3}$ \\
\hline Formal & $6,405,953$ & $6,527,120$ & $6,812,647$ & $6,841,877$ & $6,872,924$ & $7,033,940$ & $7,460,398$ \\
\hline $\begin{array}{l}\text { Commercial } \\
\text { Agric. }\end{array}$ & 495,530 & 726,249 & 804,034 & 666,940 & 665,941 & 810,998 & 831,893 \\
\hline $\begin{array}{l}\text { Subsistence } \\
\text { Agric. }\end{array}$ & 163,422 & 202,290 & 286,856 & 964,837 & 358,983 & 520,259 & 350,384 \\
\hline Informal & 965,669 & $1,077,017$ & $1,573,986$ & $1,933,675$ & $1,873,136$ & $1,702,415$ & $1,899,114$ \\
\hline Domestic & 992,341 & 749,303 & 798,524 & 999,438 & 915,831 & 875,255 & $1,022,921$ \\
\hline Unspecified & 70,986 & 107,966 & 92,905 & 305,797 & 146,000 & 85,841 & 57,534 \\
\hline Unemployed & $2,450,738$ & $3,162,662$ & $3,157,605$ & $4,082,248$ & $4,525,309$ & $4,837,493$ & $4,570,566$ \\
\hline $\begin{array}{l}\text { Not eco } \\
\text { active }\end{array}$ & $13,960,772$ & $13,156,940$ & $12,752,967$ & $11,100,135$ & $12,006,413$ & $12,118,060$ & $13,724,114$ \\
\hline Total 15-65 & $25,505,411$ & $25,709,548$ & $26,279,523$ & $26,894,948$ & $27,364,538$ & $27,984,260$ & $29,916,924$ \\
\hline
\end{tabular}

Source: Own calculations from October Household Survey and Labour Force Surveys 
Figure 2: Labour Force by Type of Work in South Africa, 1997-2003

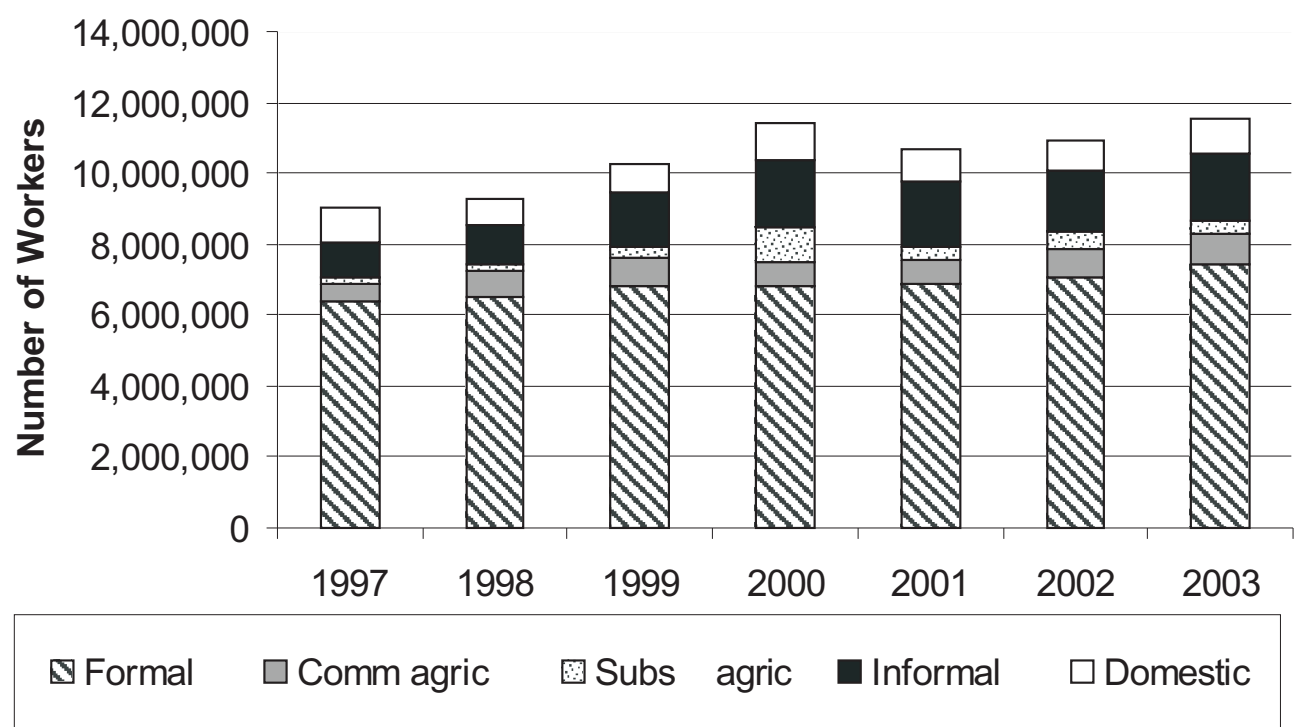

Source: Own calculations from October Household Survey and Labour Force Surveys

Drawing on the latest available figures - the March 2004 LFS - Figure 3 shows the distribution of workers operating in informal enterprises by industrial sector. Employment in informal enterprises in South Africa is concentrated in trade, with just under half of all informal workers located in this sector (Figure 3). Further, there are significant numbers of people working in construction, manufacturing and services. In comparison to other developing contexts South Africa's informal economy is disproportionately dominated by trade (see Charmes' 2000 figures for other African countries). 
Figure 3: Workers in Informal Enterprises by Sector, March 2004

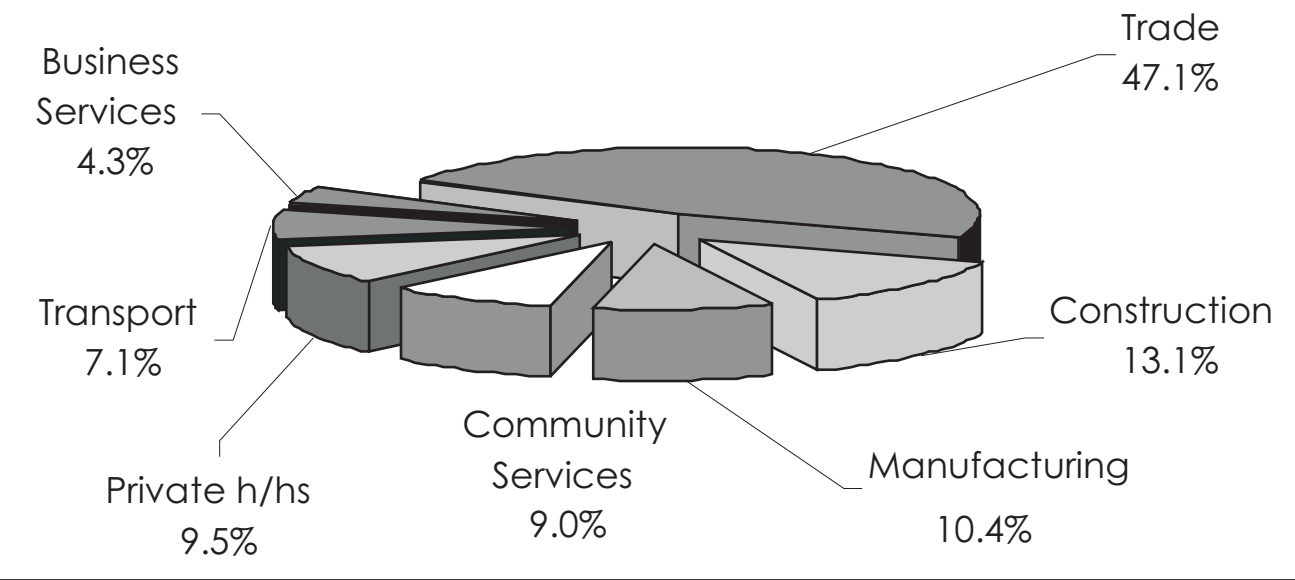

Source: Own calculation from LFS, March 2004

Figure 4 shows monthly incomes of workers in informal enterprises. According to the survey 51 per cent of those working in informal enterprises earn R500 or less (with a significant number of people reporting earning nothing) and that 92 per cent earn less than R2 501 . This suggests a correlation between being poor and working in the informal economy. This relationship is confirmed in previous analyses using LFS data (see for example Meth, 2002). 
Figure 4: Incomes in the Informal Enterprises, March 2004

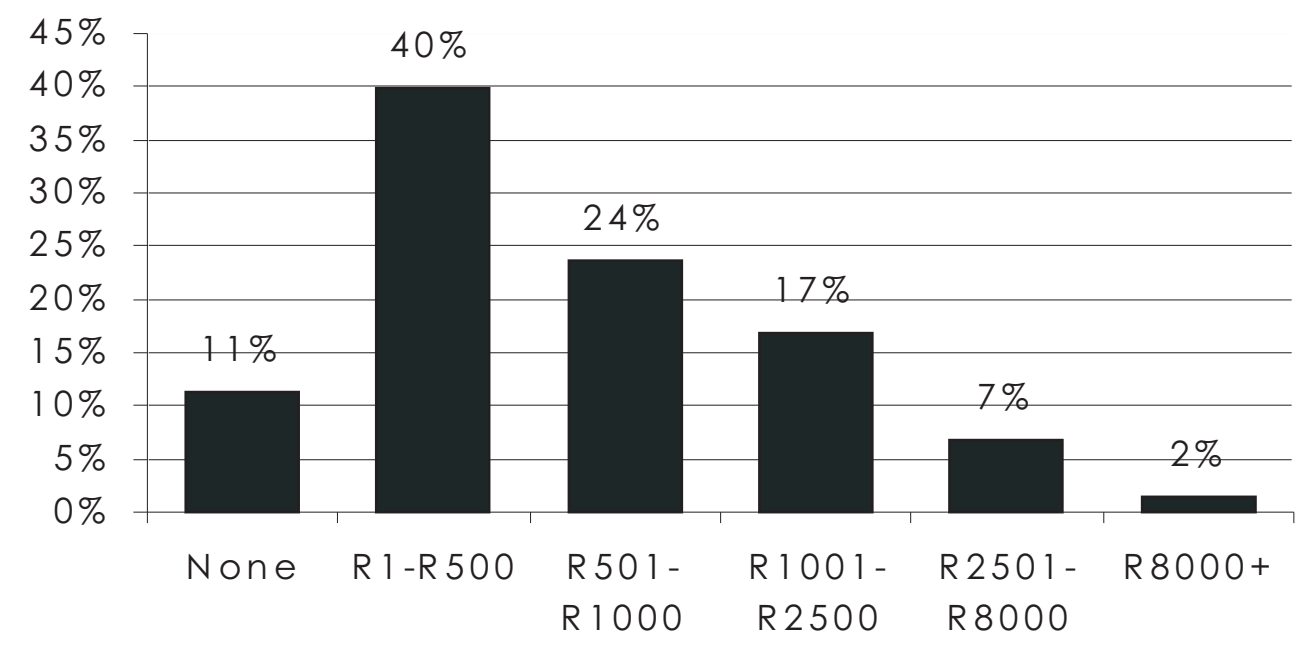

Source: Own calculation from LFS, March 2004

Table 3 contains summary statistics about the sex and race of those working in the formal economy, informal enterprises and domestic work. As is the case internationally ${ }^{5}$, there is a gender dimension to informal work in South Africa. Although more men than women work in the informal economy, the difference is less than is the case for the formal economy (Table 3). It is also significant that the overwhelming majority of domestic workers are women. Within the informal economy smaller scale surveys and qualitative research indicates that women tend to be over represented in the less lucrative activities (see for example Lund's 1998 gendered re-analysis and synthesis of research on street trading). Finally, with respect to race, the majority of those working in informal enterprises are black.

5 See Sethuraman (1998) for an international gendered analysis of informal sector statistics. Having reviewed substantial country specific data he suggests that in the informal sector women's incomes are lower than those of men and that the proportion of women in lower income categories is greater. Sethuraman reports this gender inequality for all countries in Asia, Africa and Latin America from which evidence is drawn. 
Table 3: Formal, Informal Employment and Domestic Work by Sex and Race

\begin{tabular}{|c|c|c|c|c|}
\hline & Formal & Informal & Domestic & $\begin{array}{l}\text { \% of } \\
\text { Economically } \\
\text { Active } \\
\text { Population }\end{array}$ \\
\hline Male & $61.9 \%$ & $57.9 \%$ & $3.8 \%$ & $52.3 \%$ \\
\hline Female & $38.1 \%$ & $42.1 \%$ & $96.2 \%$ & $47.6 \%$ \\
\hline Black & $60.1 \%$ & $89.3 \%$ & $89.7 \%$ & $79.7 \%$ \\
\hline Coloured & $14.3 \%$ & $4.8 \%$ & $10.2 \%$ & $8.9 \%$ \\
\hline Indian & $4.6 \%$ & $1.2 \%$ & $0.0 \%$ & $2.4 \%$ \\
\hline White & $20.9 \%$ & $4.7 \%$ & $0.0 \%$ & $8.9 \%$ \\
\hline
\end{tabular}

Source: Own calculations from LFS, March 2004

In summary, a large number of South Africans work in the informal economy and this component of employment is increasing. The South African informal economy is disproportionately dominated by the retail and wholesale trade. Further there is a close correlation between being poor and working in the informal economy. Finally there is a gender and race dimension to informal work. 


\section{Government Policy on the Informal Economy}

In its policy proposals, the small business sector is sometimes seen by the South African government as the panacea for South Africa's employment and growth problems. The Department of Trade and Industry (DTI) is charged with the responsibility of developing and implementing policy for the small, medium and micro-enterprise sector (SMME). The government's 1995 White Paper (WP) on SMME's was one of the first policy documents of the new government. The WP distinguishes four categories of SMMEs; medium enterprises (assets of about R5 million), small enterprises (employ between 5 and 50), micro-enterprises (involving owner, some family members and one or two employees) and survivalist enterprises (activities by people unable to find a job). The WP recognises that the survivalist sector has the largest concentration of women and lists as one of its key objectives to 'support the advancement of women in all business sectors'. The WP recommends different support strategies for each of the four categories. Whilst outlining concrete proposals for the small, medium and micro categories, the paper is mute on support strategies for the survivalist category.

There is evidence that this omission has continued in policy implementation in the post-apartheid period. There are three main DTI small business support programmes Khula Enterprise Finance Facility, Manufacturing Advice Centres and Ntsika Enterprise Promotion Agency. Khula operates as a wholesaler of finance to the retail banking sector. It provides a range of credit guarantee mechanisms which are designed to reduce the risk on SMMEs' loans, thereby encouraging commercial banks to provide finance to those operating in the SMME sector. The responsibility for risk assessment remains with the commercial banks who each apply their own criteria, most often requiring the minimum of a business plan. This has the effect of excluding most informal economy workers from accessing Khula-backed financial services. The Manufacturing Advice Centres offer sector-specific advisory services to manufacturing SMME's to enable them to increase their productivity and improve their international competitiveness. Most assessments of the NAMAC programme conclude that they have been successful in meeting these objectives (see Rogerson, 2004). However, given their focus on manufacturing, and the nature of their objectives and programmes, the activities of the manufacturing advice centres are unlikely to filter down to informal economy workers. Ntsika provides a range of facilities to small business including management and enterpreneurship schemes, technology transfer schemes, market access and business development programmes through a network of Local Business Services Centres (LSBCs). By 2003, some 92 LSBCs had been established (Rogerson, 2004:3). The focus of Ntsika's programmes is on assisting SMME's to improve their market access and to improve their international competitiveness. Much of this focus is implemented by assisting SMME's to access government contracts and to penetrate export markets. Both of these objectives have little or no relevance to those working in the informal economy. Rogerson's (2004) assessment of government's support programmes for SMME's argues that, "during the period 1994-2003 DTI funding allocations for SMMEs have 
inevitably favoured and been biased heavily towards support for established small and medium enterprises (often white owned) rather than emerging micro-enterprises and the informal economy" (2004:9). Rogerson concludes that "current national support programmes offer little in the way of support for survivalist enterprise, women entrepreneurs and rural SMMEs" (2004:7).

The scenario of the informal economy falling through policy gaps is echoed with respect to access to training services. There are two potential routes whereby those working in the informal economy can access training - the Sector Education and Training Authorities (SETAs) and the National Skills Fund. As we have outlined in more detail elsewhere (Devey, Skinner and Valodia, 2003) this system does not adequately service those working in the informal economy. The SETA's are funded through the skills levy which is paid by employers who are registered - and thus in the formal economy - and whose annual wage bill is more than R250 000. There is evidence that SETAs tend to prioritise the needs of those contributing to the skills levy. The National Skills Fund relies on training providers responding to incentives. Training providers are often reluctant to service those in the informal economy. The reasons include the lack of profitability because workers cannot cover the costs, the low levels of education of workers, their mobility and thus difficulties of accessing workers, the need to develop non-traditional methods and the fact that many trainers are afraid to enter the areas where people need to be trained (Devey et al 2003:159-160).

The informal economy surveys conducted in Johannesburg and Durban as part of a suite of local economic development surveys included questions on access to support services. In both cases the sample sizes were just over 500 interviews, with respondents operating in a variety of different activities. The field work was conducted in 1999 and 2002 in Johannesburg and Durban respectively. In Johannesburg, of the 12 per cent of enterprise owners who reported trying to obtain a loan from a bank or any other credit institution, only 18 firms were awarded the loan (Chandra and Rajaratnam, 2001:36), while in Durban, of the 14.2 per cent who had tried to obtain a bank loan for business purposes, only 20 were successful (Skinner, 2005:35). This demonstrates an extremely low level of access to credit. In Johannesburg 81 per cent of all enterprise owners reported that they had never received any business assistance or assistance with training (Chandra and Rajaratnam, 2001:46), while in the Durban Survey 88 per cent of respondents had never received help through training or any other assistance programme (Skinner, 2005:41). In both cases, of those who had managed to access assistance, it was mostly training. The suppliers of this training were often the private sector or non-governmental organisations. In the Durban survey there were only two cases were an enterprise owner had received assistance from a SETA (Skinner, 2005:41). Skinner (2005:iii) concludes that the survey demonstrates how national government support programmes have had little or no impact on those working in the informal economy in Durban. 
Budlender et al (2004) analyse the budget allocations and programmes of most national government departments to assess the extent and efficacy of support measures for the informal economy. They find that the initiatives at national government level are piecemeal. Their trawling through department budgets, annual reports and other documentation 'suggests that the approach of most departments' is to showcase some or other programme aimed at the poor and marginalised, however small that initiative is in absolute terms. Further, the support often intersects with informal work through specific poverty relief funding. National government lacks a coherent policy on the informal economy and this is reflected in the lack of a coherent programmatic approach to dealing with developments, and supporting economic activity in the informal economy' (Budlender et al, 2004: 86).

An exception to this at the provincial and local government level, is the case of the province of KwaZulu-Natal (the provincial case study of Budlender et al (2004)), and more particularly in eThekwini (Durban, their local government case study). Here, the informal economy is recognised as an integrated component of the economy, and support for informal economy economic activity is based on a coherent and overarching policy. The result is that budgetary support for the informal economy recognises the particular nature of work in the informal economy and support measures, with a few exceptions, are appropriate for these activities. 


\section{Linkages between the Formal and Informal Economy}

Drawing on work by Devey and Valodia (2005) we make observations about the informal economy and use this to make some comments about the usefulness and correctness of the argument that is made by the President and more generally in government about the 'second economy'.

One of the arguments the President and the ANC make is that the second economy contributes 'little to GDP'. In fact, the informal economy contributes somewhere between seven and twelve per cent of GDP. In its estimates of GDP in South Africa, the South African Reserve Bank uses expenditure surveys of households to estimate the contribution of the informal economy which it captures via its estimates of private consumption expenditure of households. On this basis, the informal economy contributes some 7 per cent of GDP. Using an alternative methodology, Budlender, Buwembo and Shabalala (2001) estimate that the informal economy contributes between 8-12 per cent of gross domestic product.

A particular problem in policy terms for those working in the informal economy is the idea of the second economy being 'structurally disconnected from the first'. Case study evidence indicates that there are multiple forward and backward linkages between formal and informal activities. For example, Ince's (2003) work on informal clothing manufacturing in a residential area in Durban demonstrated that not only do manufacturers source their inputs in the formal economy, but the garments often end up in formal retail stores. Witt's (2000) work on informal fruit and vegetable distribution demonstrates multiple linkages. It is these linkages which, in policy terms, are often the most interesting areas to be concentrating on.

The panel component of the Labour Force Survey allows us to explore dynamics in the labour market. The sampling design of the LFS, which is conducted bi-annually in March (previously February) and September allows for 80 per cent of the sampling in each wave to remain in the sample. Thus households remain in the sample over five waves of the LFS. We explore these dynamics beginning in February 2002 for five waves of the LFS ending in March 2004. Matching the individuals in these households over the period, we are able to get some indication of the extent to which workers move between employment and unemployment, and when employed between different segments of the economy, such as formal and informal. ${ }^{6}$ In total, we're able to match 5587 individuals over the period.

6 Note that the panel component of the LFS allows us to track households not individuals over the five waves of the survey. We have examined the sex and age profiles of workers in these households to confirm that the individuals remain in the panel. We have thus removed from the panel all households where the individuals inside the household may have changed (through, for example, migration). 
Table 4 gives a broad overview of how the status of these workers changed over the period. The data shows that there is a surprising level of churning within the labour market, with the status of more than half of the workers having changed at least once over the period February 2002 to March 2004. As is to be expected, for those workers whose status remained unchanged, most tended to be employed in the formal sector, or remained economically inactive. Only 1.3 per cent of the 5587 workers that remained in the panel continued to work in the informal economy over the period under consideration.

Table 4: Labour Market Status, February 2002 to March 2004, n=5587

\begin{tabular}{|l|r|r|}
\hline Type of Worker & Frequency & Percent \\
\hline $\begin{array}{l}\text { Remained in the formal } \\
\text { economy }\end{array}$ & 1,175 & 21.0 \\
\hline Remained economic inactive & 1,077 & 19.3 \\
\hline Remained in commercial agric. & 99 & 1.8 \\
\hline $\begin{array}{l}\text { Remained as a domestic } \\
\text { worker }\end{array}$ & 89 & 1.6 \\
\hline Remained unemployed & 74 & 1.3 \\
\hline Remained as informal worker & 71 & 1.3 \\
\hline Worker status changed & 3,002 & 53.7 \\
\hline & 5,587 & 100.0 \\
\hline
\end{tabular}

Source: Authors' calculations from various LFSs

In Table 5 we remove from the panel all workers who did not engage in informal economy activities over the period i.e. we retain only workers who have been engaged in informal economy activities for at least one period. This reduces the number of workers from 5587 to 1009 . Again, we see a surprising level of churning occurring, with only 7 per cent of workers remaining as informal workers over the entire period. 
Table 5: Labour Market Status of Informal Economy Workers, February 2002 to March 2004, $n=1009$

\begin{tabular}{|l|r|r|}
\hline Type of Worker & Frequency & Percent \\
\hline $\begin{array}{l}\text { Informal for 5 } \\
\text { periods }\end{array}$ & 71 & 7.0 \\
\hline $\begin{array}{l}\text { Informal for 4 } \\
\text { periods }\end{array}$ & 88 & 8.7 \\
\hline $\begin{array}{l}\text { Informal for 3 } \\
\text { periods }\end{array}$ & 106 & 10.5 \\
\hline $\begin{array}{l}\text { Informal for 2 } \\
\text { periods }\end{array}$ & 202 & 20.0 \\
\hline $\begin{array}{l}\text { Informal for 1 } \\
\text { period }\end{array}$ & 542 & 53.7 \\
\hline & 1,009 & 100.0 \\
\hline
\end{tabular}

Source: Authors' calculations from various LFSs

Table 6 shows the movement of workers that were employed in the informal economy in any one period over the panel. As is to be expected, a large number of workers moved between the informal economy and being unemployed or economically inactive. A significant proportion of workers (18.3 per cent) moved between formal and informal employment.

Table 6: Shifts between Informal Work and Other Labour Market Status

\begin{tabular}{|l|r|r|}
\hline Type of Change & Frequency & Percent \\
\hline $\begin{array}{l}\text { Informal and unemployed and not economically } \\
\text { active }\end{array}$ & 191 & 18.9 \\
\hline Informal and not economically active & 190 & 18.8 \\
\hline Informal and formal & 185 & 18.3 \\
\hline Informal, formal and unemployed & 77 & 7.6 \\
\hline Informal, formal and not economically active & 73 & 7.2 \\
\hline Remained in informal & 71 & 7.0 \\
\hline Informal and unemployed & 60 & 5.9 \\
\hline Informal, formal, unemployed and not & 44 & 4.4 \\
\hline economically active & 118 & 11.7 \\
\hline Other & 1,009 & 100.0 \\
\hline
\end{tabular}

Source: Authors' calculations from various LFSs

If we reduce the period under consideration to six months, between September 2003 and March 2004, we still find fairly high levels of churning in the labour market. Of individuals recorded as informal workers in September 2003, in March 2004, 44.5 per cent reported working in informal economy, 17.3 per cent reported working in formal economy, 11.4 per 
cent reported being unemployed and 23.7 per cent reported being not economically active. Of individuals recorded as formal workers in September 2003, in March 2004, 3.4 per cent reported working in the informal economy.

These linkages between employment in the formal and informal economy are corroborated by other studies. Devey et al (2006) show that many workers classified as formal workers have employment characteristics that are consistent with informal work. There is also significant evidence, from micro-level studies which highlight the growing informalisation of previously formal work. Kenny (2000:3) in her analysis of the retail sector, not only demonstrates that casual and subcontracted labour constitutes up to 65 per cent of total employment, but highlights how core tasks like shelf packing are increasingly now done by employees of labour brokers, contracted by suppliers. Skinner and Valodia's (2001) analysis of the Confederation of Employers South Africa (COFESA) a labour consultancy that assists companies to restructure their workforces, to change employees to contractors and to outsource production to them, reveals COFESA firms no longer have to adhere to collective agreements on minimum wages or contribute to any of the benefit or training schemes. In the work place, other than changes in labour conditions, everything else remains the same. Skinner and Valodia demonstrate how by the end of 2000 COFESA estimated that this had resulted in the establishment of over 700000 independent contractors. COFESA members are involved in many different sectors, notably footwear and clothing manufacturing and also food, farming, transport, construction and engineering. The legislative loophole in the Labour Relations Act that COFESA was using has recently been changed. It is unclear whether the processes COFESA set in place have been reversed. Almost all interviewees in Theron and Godfrey's (2000) study of stakeholders from numerous industries - retail, mining, manufacturing (food, clothing, metal and engineering) catering and accommodation, construction and transport - reported an increase in the use of labour brokers and employment agencies (2000:27).

Using the KwaZulu-Natal Income Dynamics Survey (KIDS) ${ }^{7}$ Lebani and Valodia (2005) explore employment transitions in households between 1993 and 1998. They find evidence of an intra-household link between self-employment activities and formal economy workers. This association suggests that there is a transfer of human and financial capital by the formally employed to self-employment activities since it is the households that have some form of regular income that are mostly involved in self-employment initiatives. 


\section{Conclusion}

President Mbeki's recent preoccupation with the 'second economy' has undoubtedly raised the profile of an area of employment that has received little policy attention in the last 10 years. National government lacks a clear and coherent policy toward the informal economy. National government needs to urgently develop a policy on the informal economy and provide programmatic support. Given the 'space' created by Mbeki, this may be a particularly opportune moment for policymakers to more seriously consider developments in the informal economy, and to develop a coherent policy to inform programmatic support for informal economy activities.

However, the evidence that we have provided in this paper suggests that the informal economy is not, as suggested by the ANC, structurally disconnected from the formal economy. In fact, the data that we have provided on employment suggests that large numbers of workers may be moving regularly between the formal and informal economy. At the household level, there seems to be an important link between household members' access to employment in the formal economy and informal economy activities. Further, we have argued that much of what is considered to be the 'formal economy' is being informalised.

It is important that government recognises these linkages and develops policy appropriate for the informal economy. Understanding the linkages between formal and informal activities, and the fact that, like the formal sector, the informal economy is made up of a heterogeneous set of economic activities would point to policy which has to be sectorally-based. Internationally there is a trend to apply the commodity chain or value chain approach to growing the informal economy (see for example, McCormick and Schmitz, 2002). This entails detailed sector or industry level analyses outlining the process from product inception to final consumption and identifying the role of those working in the informal economy at each stage. In the process, key policy and project level interventions can be identified to expand the sector and enhance the incomes of those working within it. A good South African example of this is the research and project interventions on the traditional medicine sector in KwaZulu-Natal (See Institute for Natural Resources, 2003 for further details). Similar sectoral analyses should be conducted in the segments of the informal economy that both contribute to economic growth and where there are large numbers of people working e.g. clothing, craft, fruit and vegetable distribution and waste collection.

The most critical weakness of government policy with respect to the informal economy is one of perception of the informal economy rather than one just of policy design. The 'second economy' arguments of the President and the government are based on the premise that the mainstream of the economy is working rather well, and government action is now needed to enhance the linkages between the first and second economy, and where appropriate to 
provide relief, such as public works programmes, to those locked in the informal economy. This dualist conception of the economy is misguided not only because it hides some of the 'losers' of government's policies but also because it continues to keep elements of our economy invisible and therefore outside of the mainstream of economic and social debate. Instead, as we have demonstrated, the economy is integrated and government needs to view the informal economy as an integrated and, unfortunately, a growing part of our economy. Rather than design policy for the 'second economy' government needs to ensure that its current policies cater for the realities of our economy and also ensure that support measures are appropriately designed to reach those operating at the lower rungs of our economy. 


\section{References}

Aliber, M (2003) Small-scale agriculture as revealed by the Labour Force Survey. Unpublished mimeo, Human Sciences Research Council.

Bromley, R (1995) Informality, de Soto Style: From Concept to Policy. In Rakowski, C. (Ed.) Contrapunto The Informal Sector Debate in Latin America, Albany: State University Press of New York.

Budlender, D, Buwembo, P and Shabalala, N (2001) The Informal Economy: Statistical Data and Research Findings; Country Case Study: South Africa. Document prepared for WIEGO.

Budlender, D, Skinner, C and Valodia, I (2004) Budgets and the Informal Economy: An Analysis of the Impact of the Budget on Informal Workers in South Africa, School of Development Studies, University of KZN.

Chandra, V and Rajaratnam, B (2001) Constraints to Growth and Employment in the Informal Sector: Evidence from the 1999 Informal Survey Firm. Washington: World Bank.

Castells, M and Portes, A (1989) World Underneath: the Origins, Dynamics, and Effects of the Informal Economy. In: A. Portes, M. Castells \& L. A. Benton (eds) The Informal Economy. Baltimore: The Johns Hopkins Press. p.11-37.

Charmes, J (2000) Size, Trends and Productivity of Women's Work in the Informal Sector and in Old and New Forms of Informal Employment. An Outlook of Recent Empirical Evidence. Paper presented at the International Association for Feminist Economics, Istanbul, August.

Chen, M (2001) Women in the Informal Sector: A Global Picture, The Global Movement. SAIS Review, Vol. XXI No.1.

Devey, R and Valodia, I (2005) Formal and Informal Economy Linkages. Working Paper written for the Economic and Employment Policy Programme, Human Sciences Research Council.

Devey, R, Skinner, C and Valodia, I (2006) Definitions, Data and the Informal Economy in South Africa: A Critical Analysis. In: Padayachee, V (ed), The Development Decade? Economic and Social Change in South Africa, 1994-2004. Human Science Research Council Press, Cape Town.

Devey, R Skinner, C and Valodia I (2003) Human Resource Development in the Informal Economy, Human Resource Development Biennial Directory. Human Sciences Research Council, Cape Town. 
Eapen, M (2001) Women in Informal Sector in Kerala: Need for Re-examination. Economic and Political Weekly, June 30.

Hart, K (1973) Informal income opportunities and urban employment in Ghana. Journal of Modern African Studies, 11, 61-89.

Ince, M (2003) Informal Clothing Manufacturing in a Residential Area: The Case of Chatsworth. Masters Dissertation, School of Development Studies, University of KwaZulu-Natal.

Institute for Natural Resources (2003) Strategy and Business Plan for Development of the eThekwini Medicinal Plants Industry, Report prepared for the Durban Unicity Council.

International Labour Office (1972) Employment, incomes and equality: a strategy for increasing productive employment in Kenya. Geneva: ILO.

International Labour Organisation (2002) Women and Men in the Informal Economy, A Statistical Picture. International Labour Organisation: Geneva.

Kenny, B (2000) 'We are Nursing these Jobs': The Implications of Labour Market Flexibility on East Rand Retail Sector Workers and their Households. Paper presented at the Annual South African Sociological Association, Cape Town, July.

Lebani, L and Valodia, I (2005) Self-employment in the Informal Economy and Formal Employment Linkages: An Empirical Enquiry Based on the KwaZulu-Natal Income Dynamics Survey, Unpublished paper, School of Development Studies, University of KwaZulu-Natal.

Legassick, M (1974) South Africa: Capital Accumulation and Violence, Economy and Society, III, 253-291.

Lipton, M (1985) Capitalism and Apartheid: South Africa, 1910-1986. Aldershot: Wildwood House.

Lund, F (1998) Women Street Traders in Urban South Africa: A Synthesis of Selected Research Findings. CSDS Research Report No. 15. University of Natal, Durban. (http://www.nu.ac.za/csds/).

Lund, F and Srinivas, S (2000) Learning from Experience: A Gendered Approach to Social Protection for Workers in the Informal Economy. Geneva: International Labour Organisation. (http://www.wiego.org).

McCormick, D and Schmitz, H (2001) Manual for Value Chain Research on Homeworkers in the Garment Industry. (http://www.ids.ac.uk). 
Meth, C (2002) What to do Until the Doctor Comes? Relief for the Unemployed and for Poorly Paid Workers. A background research paper prepared for the Committee of Inquiry into Comprehensive Social Security in South Africa.

Naidoo, K (2004) Operationalising South Africa's Move from Macro-economic Stability to Micro-economic Reform. Paper presented at the $50^{\text {th }}$ Anniversary conference of the School of Development Studies, University of KwaZulu-Natal, Durban, 20-22 October 2004.

O'Dowd, M (1978) The Stages of Economic Growth and the Future of South Africa, in L. Schlemmer and E. Webster (eds.), Change, Reform and Economic Growth in South Africa, Johannesburg: Ravan Press.

Padayachee, V and Valodia, I (2001) Changing Gear? The 2001 Budget and Economic Policy in South Africa, Transformation, 46, 71-83.

Peattie, L (1987) An Idea in Good Currency and How it Grew: the Informal Sector. World Development, 15(7), 851-860.

Rogerson C (2004) The Impact of the South African Government's SMME Programmes: A Ten Year Review (1994-2003). Mimeo, Department of Geography, University of Witwatersrand, Development Southern Africa, Vol. 21, No.5

Sethuraman, SV (1998) Gender, Informality and Poverty: A Global Review, Monograph. Geneva: International Labour Organisation. (http://www.wiego.org).

Skinner, C (2005) Constraints to Growth and Employment in the Greater Durban Metropolitan Area: Evidence from Informal Economy Survey, School of Development Studies Research Report, No. 65. Durban: University of KwaZulu-Natal.

Skinner, C and Valodia, I (2001) Labour Market Policy, Flexibility, and the Future of Labour Relations: The Case of Clothing, Transformation, 50.

Theron, J \& Godfrey, S (2000) Protecting Workers on the Periphery. Development and Labour Monologues I. University of Cape Town: Institute of Development and Labour Law.

Witt, H (2000) Formal and Informal Economy Linkages in the Fruit and Vegetable Sector. Study 7.3. Research Report for Durban's Technical Task Team for the Informal Economy.

Wolpe, H (1972) Capitalism and Cheap Labour-power in South Africa: From Segregation to Apartheid, Economy and Society, 1(4) 